\title{
South-South Cooperation Strategies and Business Development in Rwanda.A Case of Supporting Indian Trade and Investment in Africa (SITA).
}

\author{
Deogratias Nshimiyimana ${ }^{1}$ and Mercyline W. Kamande ${ }^{2}$ \\ ${ }^{1}$ School of Social Sciences, Mount Kenya University \\ Kigali, Rwanda \\ ${ }^{2}$ School of Business and Economics, Mount Kenya University \\ Kigali, Rwanda
}

\begin{abstract}
This research examined the contribution of SouthSouth Cooperation Strategies and Business Development in Rwanda using a case study of Supporting Indian Trade in Africa (SITA) in Rwanda. A mixed approach was adopted during research process. The target population was 17 companies benefiting from SITA support. Census sampling techniques were used to collect information from all beneficiaries. Questionnaires and interview guide were used during data collection. Statistical Package for Social Sciences version 25.0 was used for data analysis. Findings indicated a significant correlation found between Private-Private partnership and greater export flows $(r=0.215, p=0.048)$, Private-Private partnership and improved business environment $(0.512, p=0.036)$ and Private-Private partnership and improved business development $(\mathrm{r}=0.546, \mathrm{p}=0.023)$. Positive correlation was found in attendance at Buyer-Seller meeting and improved business environment $(\mathrm{r}=0.931, \mathrm{p}=0.000)$ and attendance at Buyer-Seller meeting and improved business development $(\mathrm{r}=0.558, \mathrm{p}=0.020)$. The study showed that majority are benefiting from buyer seller meeting in India. It was evidenced that SITA prepared companies how to improve materials ready for the market. The land area covered by some spices in past respective five years (2015-2019) increased by over $44 \%$. The study recommends further support to getting direct buyers, investors and post-harvest infrastructures and certification.
\end{abstract}

Key word: South-South Cooperation, SITA (Supporting Indian Trade in Africa), United Nations for South-South Cooperative and Development.

\section{Introduction}

Global community witnessed a paradigm change from north-south development cooperation to the south-south one.

The main aim was to stimulate development policies in cooperation with developing countries in Africa, Asia, Middle East and Latin America (Ayllón, 2010).

Thus, South-South Cooperation is one the most effective strategies to ensure development and reduce poverty in the south as it cuts the dependence on donor countries in the north and assists the advancement of innovation and technology while enhancing local and regional partners in development.

It is in this sense that ITC through SSC framework and under the support and mandate DFID, designed and execute a program, initially called 'supporting India's Trade Preferences for Africa (SITA) with the ultimate objective of creating income and employment opportunities in East Africa.

Therefore, the work of SITA to pursue the enhancement of various export of goods and promoting investment as tool to develop added value and setting the ground for sustainable business developmenthas served the case of this study to investigate contribution of South-South Cooperation to the business development in Rwanda. Thus, this study looked at South-South Cooperation as a development cooperation mechanism and attempted an assessment of how successful it can be in achieving the intended objectives of being an instrument in promoting 
development among developing countries. This study was carried out based on these objectives:

i. To analyze South-South Cooperation strategies adopted by SITA in promoting business development in Rwanda;

ii. To assess the level of business development by beneficiaries of SITA cooperation activities in Rwanda;

iii. To establish the relationship between development cooperation through SITARwanda and the business development of its beneficiaries.

\section{Literature review}

Ayllón (2010)asserts that South-South Cooperation is adopted to fortify the trade relations for attaining sustainable development goals, the international plan for individual, the earth and development. Previous studies indicated the role of south-south trade and investment in stimulating health, education and welfare of the population.

According to Cabral and Weinstock (2010), the South-South Cooperation include various kind that promote job creation, trade development, ameliorated infrastructure and technology transfer, promotes regional integration and benefits for all country's involvements.

UNDP attempted to involve developing countries in mutual cooperation with special emphasis to South-South framework for attaining sustainable development (Haddad, 2013). The improvement of South-South Cooperation in fortifying cooperation in terms of trade, agriculture and industry via regional and international centers of excellence will help development countries to achieve development.

In spite of all the partnerships and cooperation between developed countries and developing countries known as North-South Cooperation (Mahama, et al., 2014) reveals that international communities have utilized several strategies including development cooperation, coordination, bilateral and multinational agreements to encounter their development objectives.

In the critical review conducted, the results showed that there are still shortcomings: most of these researches reviewed were carried out on new reality of aids, prospects on the return on non-DAC in Africa, potentials of south-south cooperation in Africa and program for decentralized south-south technical cooperation, therefore, creating a literature gap.
ISSN 2455-6378

In addition, these studies focused on strategies used, but failed to take into consideration how private-private cooperation affect business development, the attendance at buyer-seller meeting, trainings through field school and marketing and branding support on development of business for beneficiaries of South-South Cooperation orchestrated by SITA project. Therefore, there is the literature gap the present research managed to bridge and fill.

\section{Materials and Methods}

This research adopted quantitative methods for empirical data in order to gather numerical data regarding the issue of the research outline. The aim of using quantitative research, was to emphasize the statistical, mathematical information collected through pre-existing data and data collected through the interviews using computational techniques. Qualitative research method was considered to describe collected data and establish correlations between dependent and independent variables and enable the study to reach its logical conclusion.

The target population of this research was comprised of companies of SITA-Rwanda, beneficiaries of SITA activities in Rwanda. The population size was 17 companies and three staff members of SITA-Rwanda. The population size was quite small. That is why census technique was applied and a study to all population was conducted, meaning that the sample size is 17 companies and three key informants.

\section{Results and Discussion}

This study analyzed South-South Cooperation strategies adopted by SITA in promoting business development in Rwanda, assessed the level of business development by beneficiaries of SITA cooperation activities in Rwanda and established the relationship between development cooperation through SITA-Rwanda and the business development of its beneficiaries.

The Strategies adopted by SITA in selected companies were private-private partnership, attendance at buyer-seller meeting, training through field school, marketing and branding support.

\subsection{Private-Private Partnerships strategies adopted SITA for business development}


Table 4. 1 Private-Private Partnership adopted by SITA.

\begin{tabular}{lcr}
\hline Private-Private Partnership adopted by SITA & \multicolumn{2}{c}{ Chili and Ginger companies } \\
& Number & Percentage \\
\hline Identification of and seizing business opportunities & 4 & 23.5 \\
Investment linkage between SITA and Companies & 5 & 29.4 \\
Business linkage & 2 & 11.8 \\
Raising business concerns & \multicolumn{1}{|c}{} & 35.3 \\
Total & & $\mathbf{1 0 0 . 0}$ \\
\hline
\end{tabular}

Source: Primary data, 2020

Findings presented in Table 4.1 indicate the perception of companies related to the contents of the private-private companies given by SITA for ginger and chili companies. These contents are dispatched in four respective contents. These are the identification of and seizing business opportunities, investment linkage between SITA and companies, business linkage, raising business concerns.

\subsection{Attendance at Buyer-seller meeting for business development}

Table 4. 2 How does SITA facilitate your company to attend international trade fares?

$\begin{aligned} & \text { How SITA facilitate your company to attend } \\ & \text { international trade fares }\end{aligned}$
$\begin{aligned} & \text { SITA introduces spices producers to importing } \\ & \text { companies in India }\end{aligned}$
$\begin{aligned} & \text { SITA facilitate the participation of selected } \\ & \text { companies to global trade fairs }\end{aligned}$

Source: Primary data, 2020

Results presented in Table 4.2 provided information on how SITA facilitate your company to attend international trade fares. In these regards, SITA facilitate companies to attend international trade fares in the following ways: SITA introduces spices producers to importing companies in India, SITA facilitate the participation of selected companies to global trade fairs. Meanwhile, 70.6\% of companies agreed that SITA introduces spices producers to importing companies in India. Furthermore, $64.7 \%$ of companies confirmed that SITA facilitate the participation of selected companies to global trade fairs. This show that majority are benefiting from buyer-seller meeting in India. The study is relevant because it confirms arguments advanced by Ladd (2010), the extent to which any state achieved economic development was done by reconsidering a range and large important indicators containing per capita income, life expectancy, education and poverty reduction.

\subsection{Training through filed school strategies adopted by SITA for business development}

Table 4. 3 Training through field schools benefited from SITA

\begin{tabular}{|c|c|c|c|c|c|c|c|c|c|c|c|c|}
\hline \multirow[b]{3}{*}{ Statements } & \multirow{2}{*}{$\begin{array}{l}\text { Strongly } \\
\text { Disagree }\end{array}$} & \multirow{2}{*}{\multicolumn{2}{|c|}{ Disagree }} & \multirow{2}{*}{\multicolumn{2}{|c|}{ Not Sure }} & \multicolumn{6}{|c|}{ Strongly } & \multirow[b]{3}{*}{ Sdv } \\
\hline & & & & & & & & & & & Total & \\
\hline & $\%$ & $\mathbf{N}$ & $\%$ & $\mathbf{N}$ & $\%$ & $\mathbf{N}$ & $\%$ & $\mathbf{N}$ & $\%$ & $\mathbf{N}$ & Mean & \\
\hline
\end{tabular}


SITA provides training on seeds preparation and growing them

Training on soil preparation

SITA provides training to staff on pre and postharvesting processing

SITA offers training on improving volume

SITA trains beneficiaries on how to improve quality of produces

SITA trains beneficiaries on quality management

$\begin{array}{llll}2 & 11.8 & 3 & 17.6\end{array}$

5.9

5.9

23.5

$\begin{array}{lll}7 & 41.2 & 17\end{array}$

$2.35 \quad 1.49$

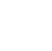

$\begin{array}{lllllllllllll}1 & 5.9 & 1 & 5.9 & 2 & 11.8 & 5 & 29.4 & 8 & 47.1 & 17 & 1.94 & 1.19\end{array}$

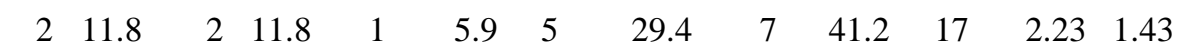

SITA provides training in a value adding activities in ginger and turmeric to staff on pre-harvesting $\begin{array}{lllllllllllll}1 & 5.9 & 2 & 11.8 & 1 & 5.9 & 4 & 23.2 & 9 & 52.9 & 17 & 1.94 & 1.29\end{array}$ processing

SITA provides training on marketing skills

211.8

11.9

5

29.4

8

$47.1 \quad 17$

$2.00 \quad 1.27$

17.6

$8 \quad 47.1 \quad 17$

$2.17 \quad 1.42$

\section{Source: Primary data, 2020}

Results presented in Table 4.3 provided information on training through field schools by SITA for beneficiaries. In this regard, $41.2 \%$ of respondents strongly agree that SITA provides training on seeds preparation and growing them, $29.5 \%$ of respondents, agreed that SITA offers the training on soil preparation, $47.1 \%$ strongly agreed that SITA provide training to staff on pre and postharvesting processing, $42.1 \%$ strongly agreed that SITA offers training on improving volume. Furthermore, $41.7 \%$ of respondents strongly agreed that SITA train beneficiaries on how to improve quality of production, and the same percentage strongly agreed that SITA trains beneficiaries on quality management. This show that majority are benefiting from training through field school.

\subsection{Marketing and Branding Support strategies adopted by SITA for business development}

Table 4. 4 Marketing and branding skills for Business Development

\begin{tabular}{|c|c|c|c|c|c|c|c|c|c|c|c|c|c|}
\hline \multirow[b]{2}{*}{ Statements } & \multicolumn{2}{|c|}{$\begin{array}{l}\text { Strongly } \\
\text { Disagree }\end{array}$} & \multicolumn{2}{|c|}{ Disagree } & \multicolumn{2}{|c|}{ Not Sure } & \multicolumn{4}{|c|}{$\begin{array}{c}\text { Strongly } \\
\text { Agree }\end{array}$} & \multirow[b]{2}{*}{$\mathbf{N}$} & \multirow{2}{*}{$\begin{array}{c}\text { Total } \\
\text { Mean }\end{array}$} & \multirow[b]{2}{*}{ Sdv } \\
\hline & $\mathbf{N}$ & $\%$ & $\mathbf{N}$ & $\%$ & $\mathbf{N}$ & $\%$ & $\mathbf{N}$ & $\%$ & $\mathbf{N}$ & $\%$ & & & \\
\hline $\begin{array}{l}\text { SITA provides training } \\
\text { on seeds preparation and } \\
\text { growing them }\end{array}$ & 2 & 11.8 & 1 & 5.9 & 2 & 11.8 & 6 & 35.3 & 6 & 35.3 & 17 & 2.23 & 1.34 \\
\hline
\end{tabular}


SITA organized marketing workshop for beneficiary companies SITA provides coaching for companies on building their brand and sales materials

SITA prepares companies how to improve materials read for the market

SITA provides training on how to add value in branded packaging through design and
211.8

211. graphics

Source: Primary data, 2020

Results presented in Table 4.4 provided information on how SITA support companies to improve marking and branding skills. In fact, SITA support companies to improve marketing and branding skills through: the provision of training on seeds preparation and growing them, SITA organized marketing workshop for beneficiary companies, SITA provides coaching for companies on building their brand and sales materials, SITA preparescompanies how to improve materials ready for the market, and SITA provides training on how to add value in branded packaging through design and graphics.

\subsection{Greater Export Flows for Beneficiaries of SITA Support in Rwanda}

Table 4. 5 Number of Spices Sold under different Zone for Selling

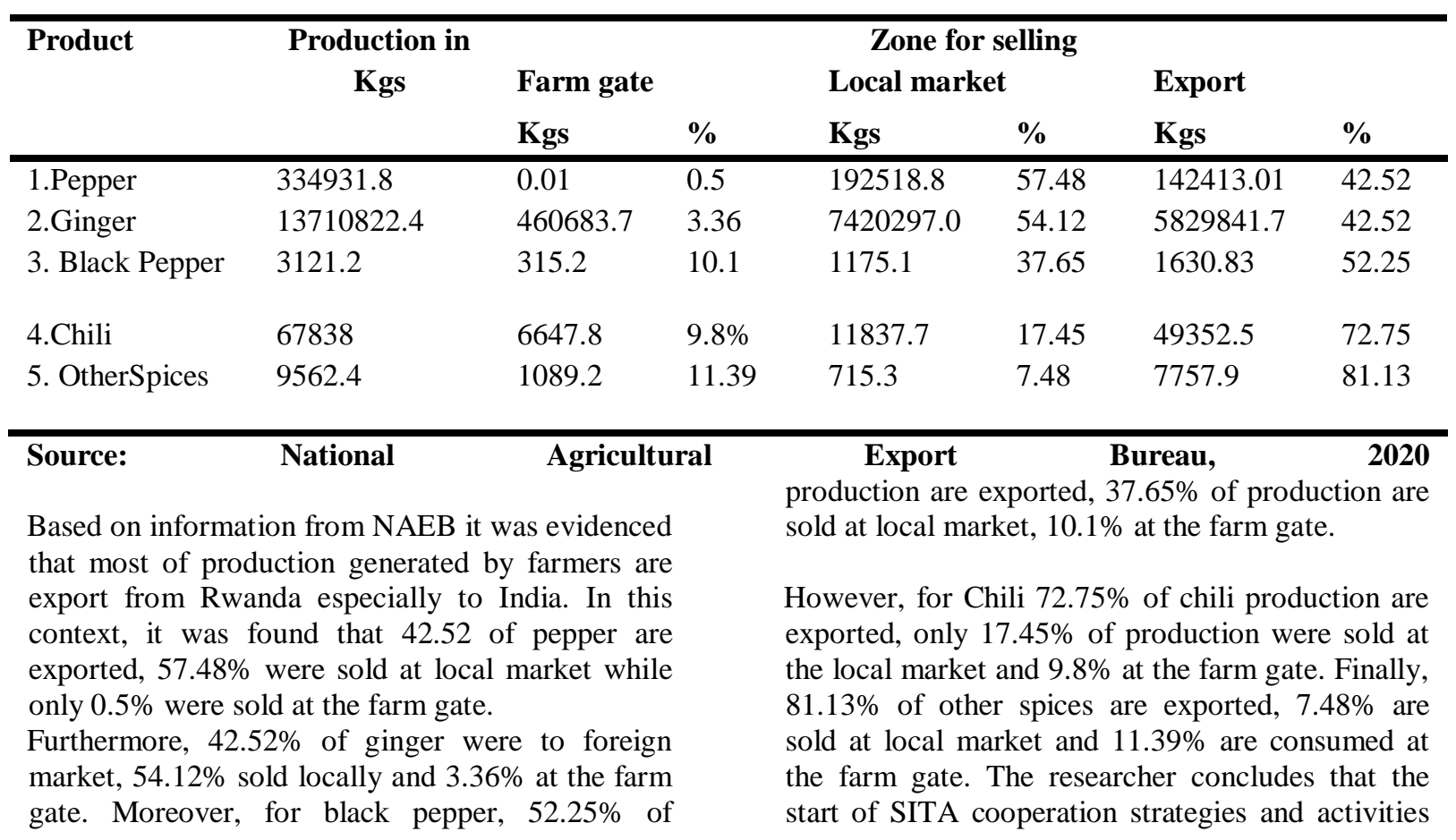


that are intended to the development of chili and ginger farmers in Rwanda lead to the export promotion and socioeconomic development of people involved in chili and ginger agriculture and business activities. This study concurs with conclusions of Mawdsley (2012) who argued that to fully involving developing countries with the international trade regime, the EU take into

ISSN 2455-6378

consideration their needs in its aid trade mechanism.

\subsection{Increased investment and Technology for Beneficiaries of SITA Support in Rwanda}

Table 4. 6 Increased investment and Technology for Beneficiaries of SITA

\begin{tabular}{llllll}
\hline Year/Area Covered in (USD) & $\mathbf{2 0 1 5}$ & $\mathbf{2 0 1 6}$ & $\mathbf{2 0 1 7}$ & $\mathbf{2 0 1 8}$ & $\mathbf{2 0 1 9}$ \\
\hline Spices Crops & & & & & \\
\hline 1.Pepper & 10526 & 12117 & 18494 & 19000 & 20512 \\
2.Ginger & 3985 & 9802 & 11241 & 14967 & 16980 \\
3. Black Pepper & 0 & 5012 & 2400 & 3100 & 3442 \\
4. Chili & 0 & 2038 & 11761 & 1761 & 1895 \\
5. OtherSpices & 1056 & 1954 & 2187 & 23127 & 2648 \\
\hline
\end{tabular}

Source: National Agricultural Export Bureau, 2020

Results indicated that farmers were able to increase their investment because of support from SITA. Information collected evidenced that since 2015 till 2019 there was an increase in term of investment and technological use in pepper, ginger, black pepper, chili and other spices. Over these years, ginger has shown an apparent progressive increase in terms investment and technology.

\subsection{Improved business environment for Beneficiaries of SITA Support in Rwanda}

Table 4. 7 Increased of Business Environment in last Five Years

\begin{tabular}{lccccc}
\hline Year/Number of Machine used & $\mathbf{2 0 1 5}$ & $\mathbf{2 0 1 6}$ & $\mathbf{2 0 1 7}$ & $\mathbf{2 0 1 8}$ & $\mathbf{2 0 1 9}$ \\
\hline Spices Crops & & & & & \\
\hline Irrigation system & 3 & 9 & 9 & 23 & 15 \\
Processing Machine & 0 & 5 & 12 & 15 & 11 \\
Drying Machine & 2 & 4 & 4 & 9 & 20 \\
Packing machine & 0 & 0 & 9 & 16 & \\
\hline
\end{tabular}

Source: National Agricultural Export Bureau, 2020

Results from the Table 4.7 demonstrated that there was an improvement in business environment. The table indicated that from 2015 to 2019, the availability of irrigation, processing, drying and packing machine used by farmers was increased due to support form SITA. Over these years, business environment was ameliorated.

Findings from this research concur with observation of Haddad (2013) which indicated that improvement of South-South Cooperation in fortifying cooperation in terms of trade, agriculture has led to the amelioration and improvement of business environment through regional and international centers of excellence will help development countries to achieve development.

\subsection{Improved business development for Beneficiaries of SITA Support in Rwanda}


Table 4. 2 Improved business development for Beneficiaries of SITA Support in Rwanda

\begin{tabular}{llllll}
\hline Year/Number of market opportunities created & $\mathbf{2 0 1 5}$ & $\mathbf{2 0 1 6}$ & $\mathbf{2 0 1 7}$ & $\mathbf{2 0 1 8}$ & $\mathbf{2 0 1 9}$ \\
\hline Spices Crops & & & & & \\
\hline 1.Pepper & 3 & 3 & 9 & 15 & 18 \\
2.Ginger & 0 & 0 & 5 & 7 & 11 \\
3. Black Pepper & 0 & 2 & 6 & 7 & 12 \\
4. Chili & 0 & 0 & 4 & 5 & 9 \\
5. OtherSpices & 2 & 3 & 6 & 10 & 15 \\
\hline Source Nati
\end{tabular}

Source: National Agricultural Export Bureau, 2020

Table 4.8 shows an increase of market opportunities created in India and other Asian countries in the last five years (2015-2019). Over these years, market for Rwandan ginger and chili was expended in term of quantity. This was relevant to the survey of Mahama, et al., (2014) on how South-South Cooperation promote job creation, trade development, ameliorated infrastructure and technology transfer, promotes regional integration and benefits for all country's involvements.

\subsection{Relationship between SITA strategies and business development}

Inferential statistic was done to investigate the correlation between SITA development cooperation strategies and business development. From correlation analysis using Statistical Package for Social Sciences version 25.0, significance level at $5 \%$ and $10 \%$ represented $*$ and $* *$ respectively. In this regard, one asterisk means that the level of significance is less than 0.5 while two asterisks mean that the level of significance is less than 0.01. Findings indicated the significant correlations found between Private-Private partnership and greater export flows $\left(\mathrm{r}=0.215^{*}, \mathrm{p}=0.048\right)$, PrivatePrivate partnership and improved business environment $\left(0.512^{*}, \mathrm{p}=0.036\right)$ and Private-Private partnership and improved business development $\left(\mathrm{r}=0.546^{*}, \mathrm{p}=0.023\right)$.

For an attendance at Buyer-seller meeting and improved business environment ( $r=0.931 * *$, $\mathrm{p}=0.000)$ and attendance at Buyer-seller meeting and improved business development $\left(r=0.558^{*}\right.$, $\mathrm{p}=0.020$ ), they were positively correlated. Insignificant correlation was found between an attendance at buyer-seller meeting and greater export grows. Given that the p value was > 0.05 suggesting that an increase in training through field school did not affect greater export growth.

Significant positive correlations were found between Training through field school and improved business environment ( $\mathrm{r}=0.986^{*}$, $\mathrm{p}=0.000$ ) and training through field school and improved business development $\left(\mathrm{r}=643^{* *}, \mathrm{p}=005\right)$ given that the $\mathrm{p}$ value was $<0.05$ suggesting that an increase in training through field school improved business environment and improved business development and the vice versa.

Positive correlation was found between marketing and branding support and improved business environment $\left(r=0.443^{*}, p=0.075\right.$ and marketing and branding support and improved business development $(\mathrm{r}=0.205, \mathrm{p}=0.431)$.

\section{Discussion}

Findings from this research is relevant with results of (Scoones, 2013), who asserts that south-south cooperation stimulates people to take part in different income generating activities.Studies have not shown the impact of SITA strategies adopted for Rwanda business development have been internship, facilitated attended attendance at buyerseller meetings, marketing and branding support, pilot-training courses on high demand skills and financial capacity support.

This research concurs with observation of Haddad (2013) which indicated that improvement of SouthSouth Cooperation in fortifying cooperation in terms of trade, agriculture has led to the amelioration and improvement of business environment through regional and international 
centers of excellence will help development countries to achieve development.

This study was relevant to the survey of Mahama et. al (2014) on how South-South Cooperation promote job creation, trade development, ameliorated infrastructure and technology transfer, promotes regional integration and benefits for all country's involvements. This study contracts the findings of Mawdsley (2012) who asserts that South-South Cooperation is stimulate health, education and welfare of the population and demonstrated a strong correlation in all parameters of business development.

\section{Conclusion}

This study analyzed South-South Cooperation strategies adopted by SITA in promoting business development in Rwanda. This shows that majority are benefiting from buyer seller meeting in India. The same number of companies evidenced that SITA prepares companies how to improve materials ready for the market. Results from the present study, complete the study conducted by MINICOM (2019) on the framework for effective trade facilities in the context of SITA cooperative framework in the 21 st century in issues higher agribusiness-oriented services. It shows the land area covered by some spices in past respective five years (2015-2019). From 2015 to 2019, it indicates an increase by over $44 \%$ within five years.

It established the correlation between SITA strategies and business development in Rwanda in the previous five years since 2016. Significant positive correlations were found between SITA development cooperation strategies (private-private partnership, attendance at buyer-seller meeting, training through field school, and marketing and branding support) and business development (greater export flows, increased investment and technology, improved business environment, improved business development). In general, all correlations were statistically significant given that the $\mathrm{p}$ value was $<0.05$ suggesting that an increase in cooperation strategies increased the business development and the vice versa.

\section{Acknowledgements}

I wish to acknowledge and thank Dr. KamandeMercyline for her invaluable contribution to this work. My acknowledgement is extended to Mount Kenya University, ITC (International Trade Center in Kigali and SITA (Supporting Indian Trade in Africa).
ISSN 2455-6378

\section{References}

[1] Anant, M. (2016). The Need for South-South Cooperation. International Policy Digest. Accessed via https://intpolicydigest.org/2016/05/23/theneed-for-south-south-cooperation/

[2] Asika, N. (2010). Research Methodology in the Behavioural Sciences. Ikeja: Longman.

[3] Ayllón, P. A. (2010). Brazilian cooperation; the constructive approaches in the emerging countries in the South. Sao Paulo University Press.

[4] Cabral, L \& Weinstock, M. (2010) Brazil: an emerging aid player, Lessons on emerging donors, and South-South and trilateral cooperation. London: ODI. Available at: http://www.odi.org.uk/resources/docs/6295 Retrieved on 28 August 2019.

[5] Dauvergne, P. \&Frias, D.B.L. (2012). The Rise of Brazil as a Global Development Power. Third World Quarterly, 33(5), 903-917.

[6] Haddad, L. (2013). Development Research: The Shape of Things to Come, In: The Guardian 16 Aug. 2013; online: http://www.theguardian.com/globaldevelopment-professionalsnetwork/2013/aug/16/development-researchfuture-impact. International Trade Center (2015). SITA at a Glance. Retrieved on 14 Nov. 2019.

[7]Mahama, A. M, Anaman, K. A \& Akoto, I.O (2014). Factors influencing householders' access to improved water in low-income urban areas of Accra, Ghana. Journal of Water and Health.12 (2), 318-331.

[8] Mawdsley, H. (2012). Program for decentralized South-South technical cooperation. Cambridge: Polity Press.

[9] Quadir, F. (2013). Rising Donors and the New Narrative of 'South-South' Cooperation: what prospects for changing the landscape of development assistance programs?" Third World Quarterly 34(2), 321-338.

[10] Rampa, F.; Bilal, S. \&Sidiropoulos, E. (2012). Leveraging South-South cooperation for Africa's development." South African Journal of International Affairs. Vol. 24, p. 837-889.

[11] Renzio, P \&Seifert, J. (2014). South-South cooperation and the future of development assistance: mapping, actors and options. Third World Quarterly (35)10, 1860-1875.

[12] Scoones. M. (2013).Harmonization and alignment: The double-edgedswords of budget support and decentralized aid administration).Copenhagen: Danish Institute for International Studies. 
[13] United Nations (2015). Meeting Coverage and Press Releases. SG/SM/17117ENV/DEV/157.

[14] United Nations Conference on Trade and Development. (2010). Economic development in Africa: South-South Cooperation: Africa and the new forms of Development Partnerships. UNCTAD/ALDC/AFRICA.

[15] United Nations for South-South Cooperative and Development (2012). Program for decentralized South-South technical cooperation. New York, USA. 